\title{
Historical perspectives of The American Association for Thoracic Surgery: Hiram T. Langston (1912-1992)
}

\author{
L. Penfield Faber, MD, ${ }^{\mathrm{a}}$ Thomas A. D'Amico, MD, ${ }^{\mathrm{b}}$ and The American Association for Thoracic Surgery \\ Centennial Committee
}

Hiram Thomas Langston (Figure 1), the 50th president of The American Association for Thoracic Surgery (AATS), was born to Alva B. Langston and Louise Diuguid Langston in Rio de Janeiro, Brazil, on January $12,1912 .{ }^{1}$ His parents, of US origin, were educational missionaries in South America. Dr Langston was educated in Brazil through his sophomore year (1928) at Collegio Batista in Rio de Janeiro, after which he completed his undergraduate and medical degrees at the University of Louisville in 1934. After internship and residency in pathology at Garfield Memorial Hospital, Washington, DC, Dr Langston moved to Ann Arbor, Michigan, where he completed residency in thoracic surgery under the direction of Dr John Alexander, 17th AATS president, and Dr Cameron Haight, 36th AATS president. It was there that he became ingrained in his approach to the surgical treatment of tuberculosis and his requirement that a complete and precise anatomic evaluation of every patient was required before a surgical procedure could be carried out.

He held a position in Ann Arbor as instructor in thoracic surgery and earned a master of science degree in surgery from 1937 to 1941. In 1941, Langston married Helen M. Orth, and they subsequently had 3 children. He then moved to Chicago and practiced at Northwestern University until 1942, when he entered the army during World War II and spent 4 years in the service (1942-1946). During the war, he served as chief thoracic surgeon for the 12th General Hospital in North Africa and Italy. Langston was ultimately promoted to major and was awarded the Bronze Star and the Ordem do Merito Aeronautico (a Brazilian Air Force award). He later described his military service, his experiences regarding chest wounds, and the way they were managed under severe conditions, in an article for the Alpha Omega Alpha Honor Society, "The 12th General Hospital.",

He returned to Northwestern in 1946 as assistant professor, but he moved to Wayne State University as associate

\footnotetext{
From the Department of Cardiovascular and Thoracic Surgery, ${ }^{\mathrm{a}}$ Rush University Medical Center, Chicago, Ill; and the Department of Surgery, ${ }^{b}$ Duke University Medical Center, Durham, NC.

Disclosures: Authors have nothing to disclose with regard to commercial support. Received for publication Nov 15, 2011; accepted for publication Dec 6, 2011.

Address for reprints: Thomas A. D'Amico, MD, Duke University Medical Center, Box 3496, Duke South, White Zone, Room 3589, Durham, NC 27710 (E-mail: damic001@mc.duke.edu).

J Thorac Cardiovasc Surg 2012;144:4-6

$0022-5223 / \$ 36.00$

Copyright $($ C 2012 by The American Association for Thoracic Surgery doi:10.1016/j.jtcvs.2011.12.007
}

professor in 1948, where he practiced with Dr William Tuttle. He later returned to Chicago in 1952 as associate professor at the University of Illinois, as well as the chief surgeon at the Chicago State Tuberculosis Sanitarium, and eventually chief of thoracic surgery at the Hines Veterans Hospital. Dr Langston became a leading expert in the surgical management of tuberculosis. ${ }^{3,4} \mathrm{He}$ insisted on preoperative bronchoscopy to exclude endobronchial tuberulosis (a contraindication to resection), as well as a precise and clear bronchogram to define the exact anatomy of the disease and to outline normal lung tissue. Dr Langston was steadfast in his regimen of only carrying out resection when he knew that he could have a favorable outcome and control the disease. Under Dr Langston's mentorship, surgical residents were trained in the art of rigid bronchoscopy and bronchography, carried out under $5 \%$ cocaine topical anesthesia. This experience was invaluable to their learning how to handle a complicated airway and also that the topical anesthetic had to be carefully administered.

In contrast to others who favored collapse therapy with thoracoplasty or paraffin packs, Dr Langston was a strong advocate of resection for cavitary tuberculosis. However, he was an innovator of the "tailoring thoracoplasty"resection of ribs 1 and 2 and one half of 3 approximately 3 weeks before a difficult planned pulmonary resection. ${ }^{5,6}$ Tailoring thoracoplasty was used for the patient who would have a small amount of residual lung tissue remaining after the resection and it was necessary to diminish the size of the thoracic cavity to accommodate the residual lung.

In addition to his interests in surgery for mycobacterial disease and empyema. ${ }^{7}$ Dr Langston is well remembered for other academic pursuits as well, about which he edited authoritative textbooks: autologous blood transfusion ${ }^{8-10}$ and postoperative radiography. ${ }^{11}$ From 1973 to 1978 , Dr Langston was involved in controversial debates regarding the relationship between age, air pollution, cigarette smoking, and the development of lung cancer. ${ }^{12,13}$

Dr Langston was also an accomplished surgical educator. At the Veterans Hospital, he developed a novel residency program in thoracic surgery in the late 1950s. His program, approved by the Residency Review Committee, was a 2-year program that included a 6-month rotation in cardiac surgery with Dr John Jones at the University of California at Los Angeles and 18 months of general thoracic surgery with Dr Langston. Dr George Lindesmith, later president of The 


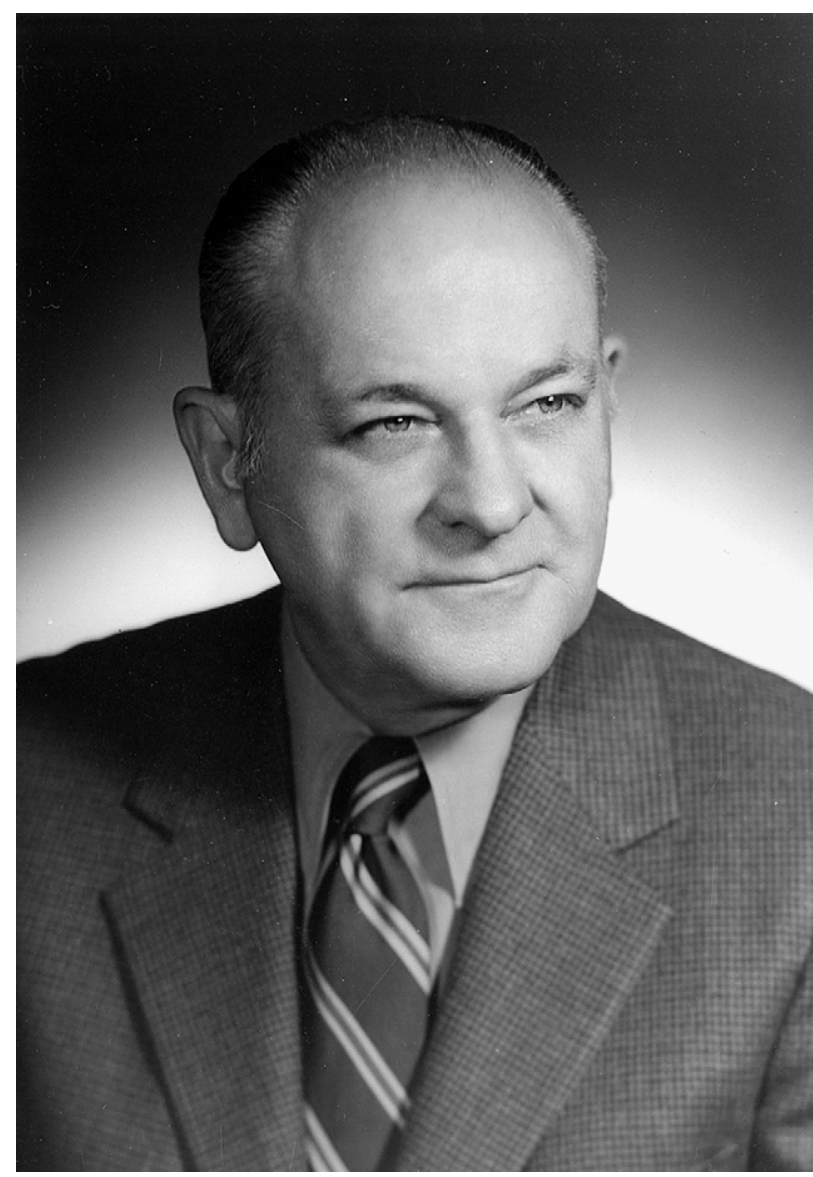

FIGURE 1. Hiram T. Langston, MD (courtesy of Northwestern University Archives).

Society of Thoracic Surgeons, was one of the first residents approved in this program and trained by Dr Langston and $\mathrm{Dr}$ Jones. The training program, under Dr Langston's direction, was rigorous and rigid.The thoracotomy was always opened and closed the same way, the pulmonary artery and veins were dissected and ligated the same way, the bronchus was sutured the same way, the segmental resection was precise and anatomic, and if the transverse process or rib was seen on an X-ray film after a thoracoplasty, the residents became acutely aware of its significance. Despite the rigor of the program, his residents were proud of having been trained by Dr Langston. His residents valued the sound and basic principles of thoracic surgery, honesty in reporting, and always striving for excellence in patient care.

He became professor of surgery and chief of thoracic surgery in 1973 at the University of Illinois Abraham Lincoln School of Medicine, and he was the chairman of the Department of Surgery at St Joseph Hospital from 1977 to 1982. $\mathrm{He}$ rejoined the Northwestern University faculty late in his career, serving from 1978 until his retirement in 1981, at which time he received emeritus status. Dr Langston eventually retired to Savannah, Georgia, where he developed a strong interest in marine biology. Hiram T. Langston, MD, died on May 20, 1992, in Chicago at the age of 80 .

Dr Langston was a founding member of the Board of Thoracic Surgery in 1948 and served as chairman of the Thoracic Surgery Residency Review Committee from 1969 to 1972 . Dr Langston was heavily involved in the AATS: secretary from 1956 to 1961, vice president from 1968 to 1969 , and finally president from 1969 to 1970 . He presided over the 50th Annual Meeting of the AATS in Washington, DC, April 5, 1970. The highlights of the semicentennial meeting included a report on the first 18 patients who underwent cardiac transplantation at Stanford, ${ }^{14}$ the initial description of the Björk-Shiley valve, ${ }^{15}$ Dr Favalaro's report of the first 401 patients at the Cleveland Clinic undergoing coronary artery bypass grafting (including the introduction of the internal mammary artery), ${ }^{16}$ the first report on the technique of mitral and tricuspid valve repair by Dr Alain Carpentier, ${ }^{17}$ the address by the honored speaker, Dr Leo Eloesser ("Milestones in Chest Surgery"), ${ }^{18}$ and Dr Langston's presidential address: "Of Cabbages-and Kings," 19 a reference to a passage in Through the Looking Glass, by Lewis Carroll (1871) ${ }^{20}$ : "The time has come," the Walrus said, "To talk of many things: Of shoes-and ships-and sealing wax, Of cabbages-and kings."

This reference alludes to the contemporaneous sense of despair and pessimism that permeated the profession of medicine in general in the era of this presidential address: "Many of these blustery winds that buffet us today are merely expressions of a society trying to find itself, but some, I fear, have a much deeper significance and are signs of illness that can and will destroy us if we do not deal with them correctly." ${ }^{19}$ A review of this address identifies issues that threaten thoracic surgery that were pertinent then and are equally pertinent now. In his clarion call to the AATS, Dr Langston concluded: "Efforts at preserving our profession...cannot be delegated in their entirety to our societies. I am certain that if we will discipline ourselves to take up individually the correction of the profession as a whole...If a sufficient number of us determine [to do so]... so that our efforts can be spread and multiplied, [this] pessimism can have no basis." As a surgeon, as a teacher, as a leader, Dr Langston epitomized the ethic of determination, precision, and high expectations.

\section{References}

1. Northwestern University. Northwestern University archives. Available at: http:// www.library.northwestern.edu/archives

2. Langston HT. The summer of ' 44 : experiences with the Twelfth General Hospital (U.S.). Pharos Alpha Omega Alpha Honor Med Soc. 1987;50:21-2.

3. Langston HT, Barker WL, Pyle MM. Surgery in pulmonary tuberculosis: 11-year review of indications and results. Ann Surg. 1966;164:567-74.

4. Zvetina JR, Neville WE, Maben HC, Langston HT, Correll NO Jr. Surgical treatment of pulmonary disease due to Mycobacterium kansasii. Ann Thorac Surg. 1971;11:551-6.

5. Langston HT. Thoracoplasty: the how and the why. Ann Thorac Surg. 1991;52: 1351-3. 
6. Barker WL. Thoracoplasty. Chest Surg Clin North Am. 1994;4:593-615.

7. Langston HT, Graham EA. Empyema thoracis. Ann Thorac Surg. 1966;2:766-8.

8. Langston HT, Milles G, Dalessandro W. Further experiences with autogenous blood transfusions. Ann Surg. 1963;158:333-7.

9. Milles G, Langston HT, Dallesandro W. Autologous transfusions. Springfield (IL): Charles C Thomas; 1971.

10. Langston HT, Callaghan RS, Mehl R. Blood for autologous transfusion. Bull Soc Int Chir. 1972;31:514-9.

11. Langston HT. The postoperative chest: radiographic considerations after thoracic surgery. Springfield, IL: Charles C Thomas; 1958.

12. Langston HT. Lung cancer-future projection. J Thorac Cardiovasc Surg. 1972; 63:412-5.

13. Langston HT. Lung cancer. J Thorac Cardiovasc Surg. 1979;77:796.

14. Stinson EB, Griepp RB, Clark DA, Dong E, Shumway NE. Cardiac transplantation in man: survival and function. J Thorac Cardiovasc Surg. 1970;60:303-21.
15. Björk VO. A new central-flow tilting disc valve prosthesis: one year's clinical experience with 103 patients. J Thorac Cardiovasc Surg. 1970;60:355-74.

16. Favaloro RG, Effler DB, Groves LK, Sheldon WC, Shirey EK, Sones FM Jr. Severe segmental obstruction of the left main coronary artery and its divisions: surgical treatment by the saphenous vein graft technique. J Thorac Cardiovasc Surg. 1970;60:469-82.

17. Carpentier A, Deloche A, Dauptain J, Soyer R, Blondeau P, Piwnica A, et al. A new reconstructive operation for correction of mitral and tricuspid insufficiency. J Thorac Cardiovasc Surg. 1971;61:1-13.

18. Eloesser L. Milestones in chest surgery. J Thorac Cardiovasc Surg. 1970;60: 157-65.

19. Langston HT. Of cabbages-and kings. J Thorac Cardiovasc Surg. 1970;60: 151-6.

20. Carroll L. Alice's adventures in wonderland and through the looking glass. New York: The New American Library; 1960:162. 